\title{
Islamic bank financing: finding the spatial effect and influencing factors from an archipelagic Indonesia
}

\section{Arief Mufraini*}

Syarif Hidayatullah State Islamic University Jakarta,

Jl. Ir. Juanda No. 95 Ciputat Raya 15412,

Tangerang Selatan Banten Indonesia

Email: ariefmufraini@uinjkt.ac.id

*Corresponding author

\section{Ahmad Tibrizi Soni Wicaksono, Kurniawati Meylianingrum and Mega Noerman Ningtyas}

\author{
Maulana Malik Ibrahim State Islamic University Malang, \\ Gejayana No. 50 Malang 65144, East Java Indonesia \\ Email: tibrizisony@uin-malang.ac.id \\ Email: meylianingrum@uin-malang.ac.id \\ Email: meganoerman@uin-malang.ac.id
}

\section{Supriyono}

Syarif Hidayatullah State Islamic University Jakarta,

Jl. Ir. Juanda No. 95 Ciputat Raya 15412,

Tangerang Selatan Banten, Indonesia

Email: supriyono_1101@uinjkt.ac.id

\begin{abstract}
In the light of Islamic bank inclusiveness, this study aims to analyse more for spatial regions effect to identify influencing factors of financing. Secondary data from 33 provinces of Indonesia took a part to complete research analysis. The findings of the research reveal such a strong spatial influence on Islamic bank financing. Jakarta and West Java Province ultimately luxuriate high value of financing, but Banten Province enjoy only low value of financing although it surrounded by the high value neighbour provinces, and Papua Province suffer from Islamic bank financing and also surrounded by the low value ones. Then it is found that Indonesia has seven provinces included in the category of neighbour less namely the Provinces of West Nusa Tenggara, North Maluku, Maluku, East Nusa Tenggara, Bali, Bangka Belitung, and Riau Islands. And factors that affect geographical spatial concentration of Islamic bank financing are gross domestic product and deposit.
\end{abstract}

Keywords: spatial regression model; Islamic bank financing and archipelagic Indonesia. 
Reference to this paper should be made as follows: Mufraini, M.A., Wicaksono, A.T.S., Meylianingrum, K., Ningtyas, M.N. and Supriyono (2020) 'Islamic bank financing: finding the spatial effect and influencing factors from an archipelagic Indonesia', Int. J. Economic Policy in Emerging Economies, Vol. 13, No. 1, pp.36-51.

Biographical notes: M. Arief Mufraini is a Senior Staff Member (Associate Professor) of Faculty of Economics and Business State Islamic University (UIN) Syarif Hidayatullah Jakarta. He is a Researcher and Faculty Manager for Theorizing on Islamic Economics and Finance Center (CTIEF).

Ahmad Tibrizi Soni Wicaksono is a Junior Staff Member of Faculty of Economics and Business State Islamic University Maulana Malik Ibrahim Malang. His research focuses on issues related to Islamic economics, Islamic banking and finance.

Kurniawati Meylianingrum is a Junior Staff Member of Faculty of Economics and Business State Islamic University Maulana Malik Ibrahim Malang. Her research interests are on Islamic finance, Islamic banking and fqih muamalah.

Mega Noerman Ningtyas is a Junior Staff Member of Faculty of Economics and Business State Islamic University Maulana Malik Ibrahim Malang. Her research focus on issues related to stock market and behavioural finance.

Supriyono is a Junior Staff Member and $\mathrm{PhD}$ candidate student on Islamic Banking and Finance Department of Faculty of Economics and Business State Islamic University (UIN) Syarif Hidayatullah Jakarta.

\section{Introduction}

At present days, due to global challenge, there are various approaches to analyse influencing factors for banking and financial industry. Identification even more interesting when it is done due to region spatial effect. Wang and Guan (2017) presented that the measurement of global financial inclusiveness results reveals a geographical spatial aggregation distribution that European and North American countries have a higher value level of financial inclusion than African and most Asian countries. The growth of banking and financing inclusion in one country has spill-over effects on their neighbourhood, influence one to another.

Zamer (2018) finds an interesting challenge of financial inclusion where the majority of population are Muslim in Middle East and sub-Sahara Africa, it was so-called, voluntary exclusion due to religious reason and the high cost of interest charged. Zamer (2018) aims to explore more for Islamic banking to offer reasonable counter for the challenges, interest is replaced with other tool based on partnership and social cooperation. Beck et al. (2019) mentioned that the attractiveness of customers to take benefit from Islamic banking services is not based on the closeness geographical location, it is more refer to the level of customer religiosity. 
A moment before Ben Naceur et al. (2015) mentioned that global financial exclusion for religious reasons seems relatively quite small, but the share varies across notably countries, African or Asian countries, and might be particularly high in certain Muslim countries. For the exclusion atmosphere, Mohieldin et al. (2012) also already persuaded that policy makers of Organization of Islamic Countries (OIC) should exploit the potential of Islamic financial instrument to achieve goal and focus on improving financial infrastructure and regulation to promote an enabling geographical environment.

Asian countries were full of archipelagic countries, whereas an agglomeration in nature, the spatial concentration or scope and scale of economic activities either gives neither positive nor negative impact to the economy of the region (Davidson and Mariev, 2018). Kolomak (2013) notes that the level of spatial concentration of economic activity and the level of interregional divergence is quite high in archipelagic country (Russia). The factors affecting spatial concentration and regional disparities were population density, size, market (financial) accessibility, and level of diversification.

Sohag et al. (2015) clarify that financial growth varies in the economies of the archipelago, sometimes, it has a negative effect on the economic growth, due to imperfect development pathway and the boom cycle, loose economy, weak financial volatility, information gaps and the banking system crisis. Conversely, gross domestic product (GDP) growth has a significant impact on the development of the banking and financial industry caused by the heterogeneous nature of the economic structure, institutional quality and financial market. Therefore, growth will be hampered due to the immature financial deepening. Soedarmono et al. (2019) convinced that at the province-level the greater of financial depth is related to the higher growth of firm performance in Indonesia. Bangake and Eggoh (2011) in such a research conducted for 71 countries explained that the growth of bank financing cannot be separated from the economic growth of a region, the higher the economic growth of a country, the more it indicates the dependence of the business sector on bank financing.

As a member of Asian countries, within the biggest country for the Muslim population, a unique archipelagic Indonesia took an active part to increase inclusiveness of emerging market of Islamic banking and finance industry. Indonesia has potentiality to become the largest Islamic financial industry country, through its superiority as a country that has the largest Muslim population, with 225 million residents or around $87.2 \%$ of the total population. Discussion above catching policy makers, the Financial Services Authority or Otoritas Jasa Keuangan (OJK) ${ }^{1}$ and Bank Indonesia (BI) ${ }^{2}$, attention to play positive role and work for relevant legislative and regulatory assistance on Islamic financial inclusion to achieve more millennium development goals and resuscitate the national and global economy. The data published by IFDR in 2018 put Indonesia in the tenth position as the country with the largest number of Islamic banking assets in the world, within the assets that reach 26.2 billion USD. This shows that the Indonesian Islamic banking industry has an important role in the community of the world as a whole.

Figure 1 shows that in 2014-2018, the growth of financing, third party funds and the number of Islamic Banking offices tended to be volatile, even though GDP was stable in the range of $4.94 \%$ to $5.18 \%$. Islamic banking market share over the past five years has only been able to penetrate the $4.83 \%$ to $5.98 \%$. While the average growth of financing reached $13.72 \%$ and growth of third-party funds by $15.35 \%$ per year. Mirzaei et al. (2013) mentioned that the rise and fall of market share affect the growth of Islamic banking through the placement of funds and financing sectors, when there is an increase in these aspects, there will be an indirect increase in the contribution to economic growth. 
Figure 1 Growth of Islamic banking in Indonesia (see online version for colours)

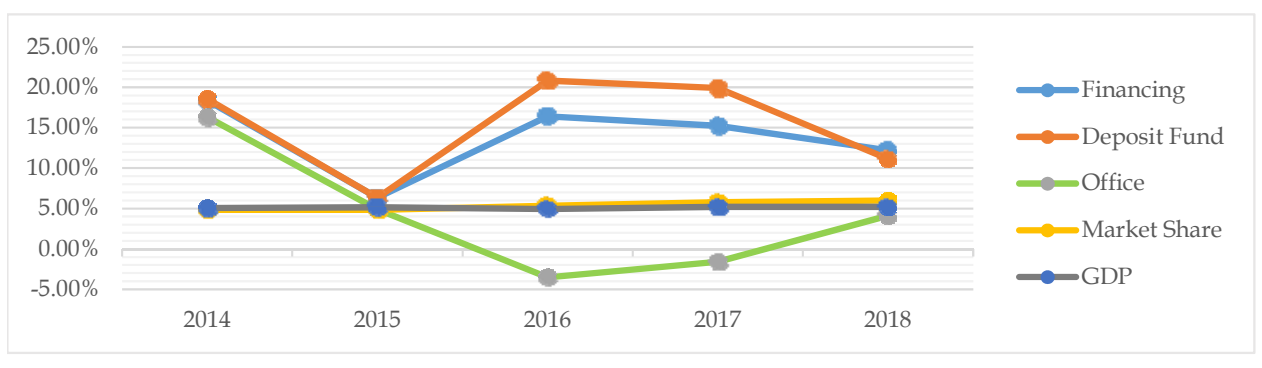

Source: Data processed from Islamic banking statistics (OJK) 2018

The OJK of Indonesia, in 2018, noted that Islamic Banking had 2,396 office networks spread across 33 provinces in the hope of increasing its own inclusion. Based on Figure 2, it is pointed out that $41.9 \%$ of total Islamic banking financing is in the provinces of Jakarta, then followed by the provinces of West Java, East Java, Central Java, Nangroe Aceh Darusalam, North Sumatra, Banten, West Nusa Tenggara, South Sumatra and Sulawesi South. Spatial concentration towards Jakarta quite indicates the existence of financial exclusion for other provinces due to Islamic bank growth. The financial exclusion shown inability of some individuals or groups to access Islamic financial system, furthermore amplifies geographical gaps in level of incomes and economic development (Leyshon et al., 2008).

Figure 2 Distribution of Islamic banking financing by province in 2018 (see online version for colours)

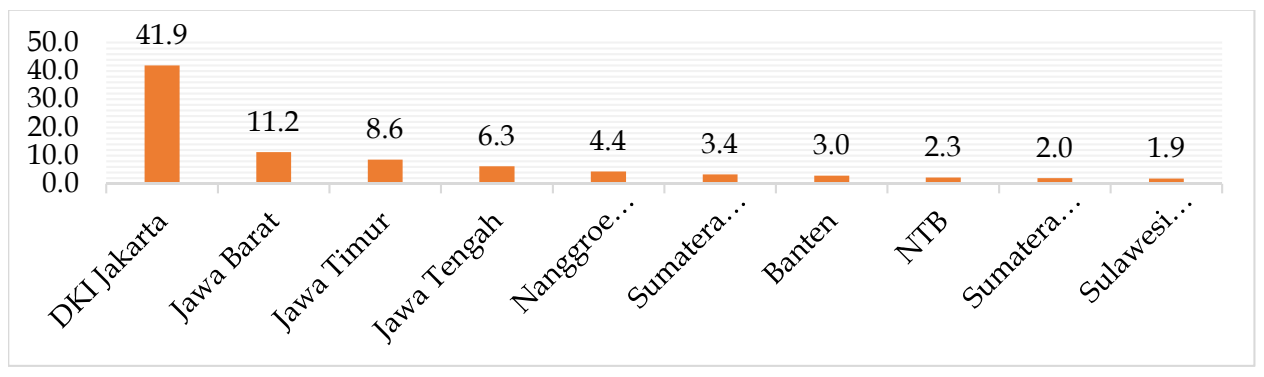

Source: Data processed from Islamic banking statistics (OJK) 2018

These discussions and data above lead researcher to see spatial effect to identify influencing factors of Islamic bank financing, knowing that Indonesia has specific interesting condition as one of an archipelagic country in Asia and economic growth has not evenly distributed among provinces.

\section{Literature review}

Collecting and landing is the ultimate activities of the banks, deposits are collected money from public and bank transfer it to economy by giving some credits to particular establishing individuals and firms. Samad et al. (2017) identify that the deposit mechanism at an Islamic bank is unique, the customer gives permission to the bank to 
invest the funds they hold for profitable business activities, the profits are distributed in accordance with the contract agreed for both bank and customer at the beginning of the agreement.

Indonesian Constitution No. 21 Year 2008 concerning Islamic banking, Article 1 states that deposits are funds entrusted by the customer to the Islamic bank and/or Islamic business unit based on a Wadia agreement or other contracts that do not conflict with Islamic principles in the form of demand deposits, savings or other forms equivalent. Third party funds held in banks are the largest source of fund as well as the most reliable. Keynes's states that savings in a country are strongly influenced by the amount of income received by the community rather than influenced by the interest rate (Sahara, 2013). Bank environment took a huge role to provide more budget to finance economy. To improve bank competitiveness would give more advantages to the world of macro economy of the country (Hakam et al., 2013).

Financing is Islamic bank terminology, it is quite the same meaning with loans or credits but both terms are different in the way of mechanism. Financing according to Bank Indonesia regulations is Islamic bank loan funds in rupiah and foreign currencies in the form of financing, accounts receivable, 'qardh', Islamic securities, placement, equity participation, temporary equity participation, commitments and contingencies in administrative accounts and 'Wadia' certificates of BI (Regulation of Bank Indonesia No. 5/7/PBI/2003). The types contracts of Islamic bank financing can be categorised into: cooperation-based or profit-loss sharing (PLS) financing such as 'Modaraba', 'Musaraka', 'Muzaraa' and 'Musaqa', sale-based financing such as 'Murabaha', 'Ijara', 'Salam', 'Istisna' and 'Qard' (Ismal, 2010) and service-based financing such as 'Wakala', 'Kefala' and 'Hawala' (Obaidullah, 2005).

Financing is a driving factor for the sustainability of banking operations. As funding increases, the function of the bank as an intermediary institution runs optimally. Financing in Islamic banking might be understood as a factor of production for individuals or companies, which should directly provide stimulus to a country's economic sector. Hachicha and Ben Amar (2015) in a study conducted in Malaysia stated that in the near future Islamic banking financing would be able to contribute directly to economic growth, this is due to application of the PLS principle (Kayed, 2012).

Gheeraert and Weill (2015) said that during periods of high session of economic growth, depositors of Islamic banks tended to place funds in the form of deposits, the behaviour of these customers provided a distinct advantage to banks by channelling more financing to business actors, ensures such a long-run economic growth (Abduh and Chowdhury, 2012; Tabash and Dhankar, 2014).

GDP shows an indicator of economic growth which is an important measure to explain economic performance directly. Combey and Togbenou (2017) revealed that real GDP growth directly affected banking growth such as increased revenue, potential for default and operational costs. The better the GDP of a country, the more banking deposits will increase, besides the higher distribution of financing, and the better return on financing (Kakilli Acaravci and Çalim, 2013; Sufian and Habibullah, 2010).

Crocco et al. (2014) stated that an area with low economic growth tends to produce an unstable pattern of financing/lending in Brazil, banking portfolio prefers to relocate financing to areas that have good economic growth. In addition, Lee and Brown (2017) 
revealed that companies located in regions with low economic growth rates often experience difficulties in the process of bank financing in the UK, this is inversely proportional to companies located in regions with high rate of economic growth. This is due to the lack of access to banking companies (Bellucci et al., 2013), and the high risk of default in areas with low economic growth (Dimitrios et al., 2016).

The regional aspect of the bank has particular effect when it is associated with the customer's residence or work location, but the implications are different empirically for both intermediary functions of the bank, which are savings and lending. Overall, it is mentioned in Turkey that the role of regions has a significant impact to increase third-party funds and financing (Basar and Genc, 2015). Marshall (2013) revealed that continuous interaction among regions is unignorable to bring out bank crisis, crisis on a region would indirectly affect the surrounding regions. Hazar and Babuscu (2013) based on regional analysis on the development of deposits and banking financing said that the greater the deposit funds, the better the financing sector, even though the purchasing power of the territory is low. Deposits are the most important resource of banking sector. While the number of deposits increases, banks will have more ability to provide financing for third parties.

The location of a branch office positively influencing to increase the number of users of financial product services, it is known that customers prefer to utilise services that are close to the location of their activities (Ansong et al., 2015). Shaffer in Richards et al. (2008) examine that the distance is an important factor to channel and limit the amount of bank financing, distance is considered to avoid the risk of default. Distance creates obstacles and problems for financing, it imposes cost on bank customers. Such a nearby customer in distance will make things easier for bank to examine and receive personal information (Liberti and Petersen, 2019).

Banks utilise the geographical proximity, indirectly, to increase market share through distribution of financing. While Hamza and Saadaoui (2013) mentioned that financing is fundamental to the sustainability of Islamic banking operations, inequality distribution of financing in each region indicates an imbalance implementation of banking business activities. Ansong et al. (2015) in their research conducted in Ghana said that the location of a branch office has an influence to increase the number of users of financial product services, customers prefer to use services whose access is not far from the location of their activities. The spread of banking offices indirectly increase the market share (Cai et al., 2016).

Jiménez et al. (2009) said that the existence of technology, and a good reputation have more affect the sustainability of a bank (Trinugroho et al., 2018), so that geographically the banking expansion - by opening more branch offices - is not sufficient to provide a significant influence to increase the amount of financing in an area. The role of the branch office only influences to determine the collateral value and at the stage of the verification process for financing applications. But it admitted that bank work more efficiently if they pay close attention the proximity of their customer (Degl'Innocenti et al., 2017; Liberti and Petersen, 2019).

Geographical superiority increases the competitiveness of Islamic banks over conventional banks (Beck et al., 2019). But for the sake of bank efficiency improving, system should influence more to regulation, market structure and economics growth 
(Soewarno and Ali, 2016). Beck et al. (2019) which states that the attractiveness of customers to work with Islamic banking services is not based on the distance or proximity between the location of the bank and the customer's place, but it is caused by the level of customer religiosity. Some customers consider Islamic bank products tend to have lower risk and stable financial structures then the conventional ones, customers preferably takes benefits from services, even though distance took a part to separate bank and customer (Abedifar et al., 2013). In the case of competition between banks, loan interest rates decrease along with the distance between companies and lending banks and increases along with distance between companies and competitor banks (Degryse and Ongena, 2005). The bank competitiveness is much related to the aggregate of macroeconomics, otherwise policy should be done through economics growth orientation (Hakam et al., 2013).

\section{Research methods}

This study aims to discuss the spatial role to identifying Islamic banking financing factors in Indonesia. The cross section secondary data employ in the form of GDP, financing, third party funds deposit and the number of Islamic banking offices for each Indonesian provinces' year 2018. The focus of this research is to put forward the spatial role of financing factors in Islamic banking, spatial pressures can be carried out through the following concepts.

Figure 3 Concept spatial regression model
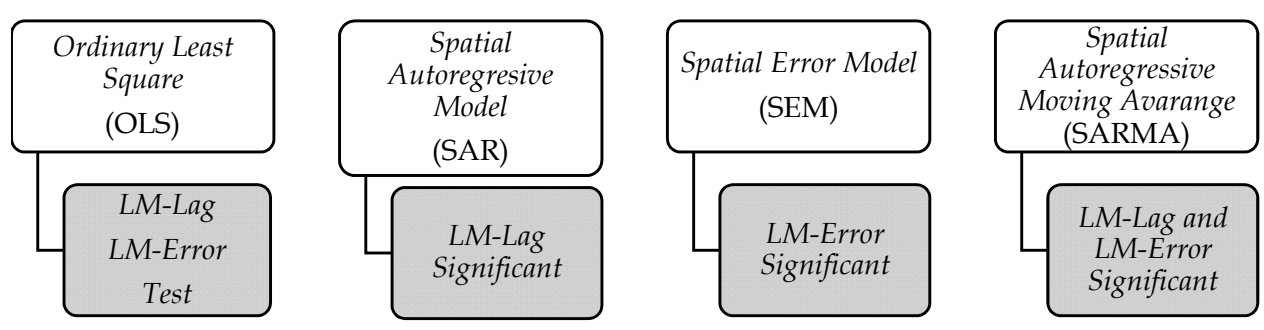

Source: Adopted from Anselin (2005).

Spatial regression is the development of the classical linear regression method. The development was based on Tobler's first geographic law which states that everything is interconnected with one to another, but that something close has more influence than something far. This means that there is a spatial or spatial influence on the data analysed (Rati et al., 2013). This concept is initiated through OLS testing using spatial weighting, then the test results are employed as a determinant of the spatial model, if the LM-Lag test results are significant then the best model is SAR, while if LM-Error is significant then the best model is SEM, however if LM-Lag and LM-Error are significant then the best model is SARMA. The data analysis method used in this research is Global Moran's testing, local indicator of spatial autocorrelation (LISA) significance map, data quality test, Lagrange multiplier which includes, spatial dependencies, SAR/SEM/SARMA and spatial rate. 


\section{Results and discussions}

\subsection{Global Moran's I test}

This test aims to see the spatial autocorrelation between locations; thus, it can be seen whether there is a spatial relationship between one location and another, through the spatial coefficient value of a location, following the Moran's I test.

Through the Queen contiguity weighting process (Figure 4), Islamic banking financing in Indonesia has a Global Moran's I value of 0.2191 and a pseudo $p$ significance value of 0.028000 , meaning that there is a strong spatial autocorrelation occurring in groups on the model. The positive autocorrelation values obtained through this test, indicate that there is a similarity of values obtained from locations that are close to and tend to be grouped, but the implementation of clustering patterns may not necessarily occur at one location, but occur in a variety of locations (Harmes et al., 2017). Spatial autocorrelation reflects dependence among spatially organised observational province in adjacent areas. Therefore, it is necessary to do LISA analysis in measuring the spatial aspects of a location.

Figure 4 Global Moran's I (see online version for colours)

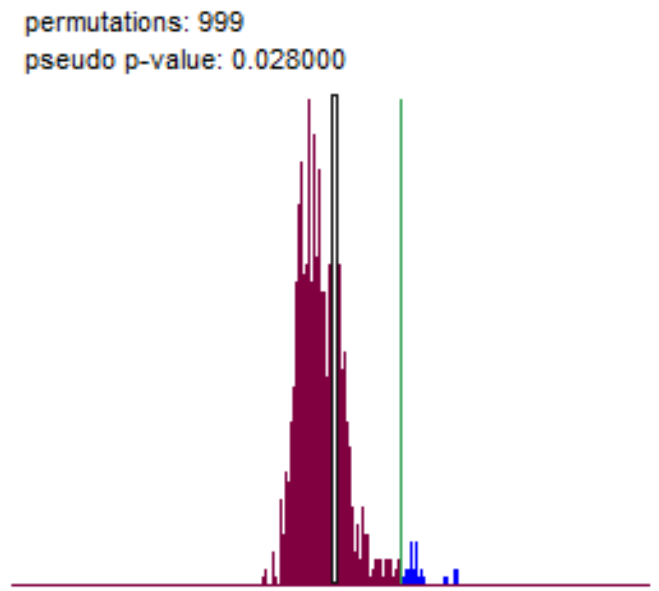

I: $0.2191 \mathrm{E}[\mathrm{]}] \mathrm{-}-0.0313$ mean: -0.0221 sd: 0.0861 z-value: 2.8025

Source: GeoDa software processed data.

\subsection{LISA test}

This test is carried out the identification process on an observation, thus the process of proving the dependence of Islamic bank financing might be spatially inter-province in Indonesia through the scatter plot, cluster map and significant map.

The results of the LISA cluster plot can be interpreted that the high and low value of financing in a province tends to be influenced by the value of financing in the surrounding provinces (Fernandez, 2011; Wang and Guan, 2017). Provinces with high level financing values tends to be neighbouring with a province that has high financing, 
thus Islamic banking needs to pay attention to the spatial aspects in the financing sector. Based on the LISA scatter plot test results (Figure 5), to mapping the four quadrants (Zhukov, 2010), it can be concluded as follows.

1 Quadrant I, (high-high) there are two provinces that have high financing values and surrounded by regions with high financing values, which are Jakarta and West Java.

2 Quadrant II, (low-high) there only one province that have low financing values however they are surrounded by regions with high financing values, which is Banten Province.

3 Quadrant III, (low-low) there are provinces that have low financing values and surrounded by provinces that have low financing values, which is Papua Province.

4 Quadrant IV, (high-low) there are no provinces that have high financing values and surrounded by provinces that have low financing values.

Figure 5 LISA scatter plot (see online version for colours)

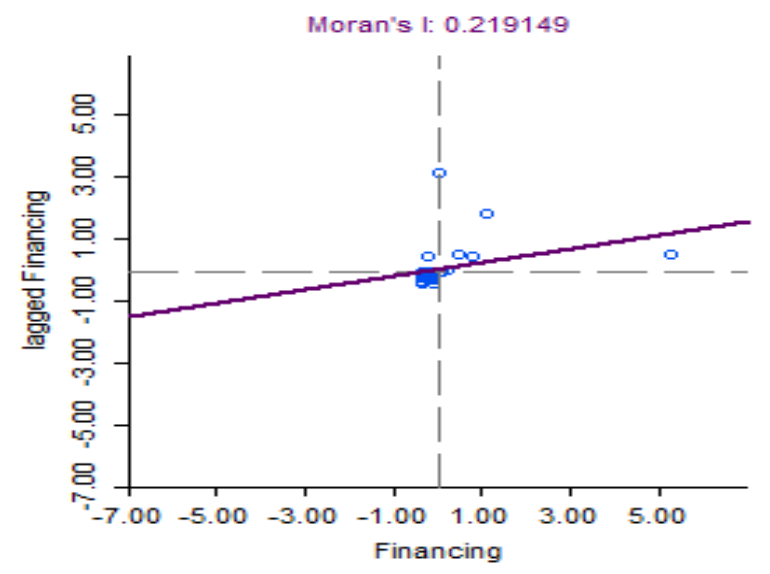

Source: GeoDa software processed data.

Results of the LISA cluster map (Figure 6) pointed out that there are 22 provinces included are not significant category, which are Gorontalo, Southeast Sulawesi, DI Yogyakarta, Central Java, East Java, South Kalimantan, West Kalimantan, South Sulawesi, Riau, Sulawesi Central, East Kalimantan, North Sulawesi, West Papua, North Sumatra, West Sumatra, Central Kalimantan, South Sumatra, Jambi, Lampung, Bengkulu, Aceh and West Sulawesi. Then it is showed also that seven provinces included in the category of neighbour less namely the Province of West Nusa Tenggara, North Maluku, Maluku, East Nusa Tenggara, Bali, Bangka Belitung, and Riau Islands.

Results of the LISA significant map (Figure 7) explained that there are local spatial autocorrelations in several provinces in financing Islamic banking in Indonesia, with a significance level of $0.05,0.01$ and 0.001 . At the significance level of 0.05 , the province was proven to have significantly autocorrelation relationship is Papua and Jakarta provinces, then there is West Java Province at a significance level of 0.01, then at the significance level of 0.001 occupied by Banten Province. LISA significant map aims to be able to show regions that have a significant level of spatial linkages between regions, with a significant value of $\mathrm{p}<0.05$ (Anselin, 2005). 
Figure 6 LISA cluster map (see online version for colours)
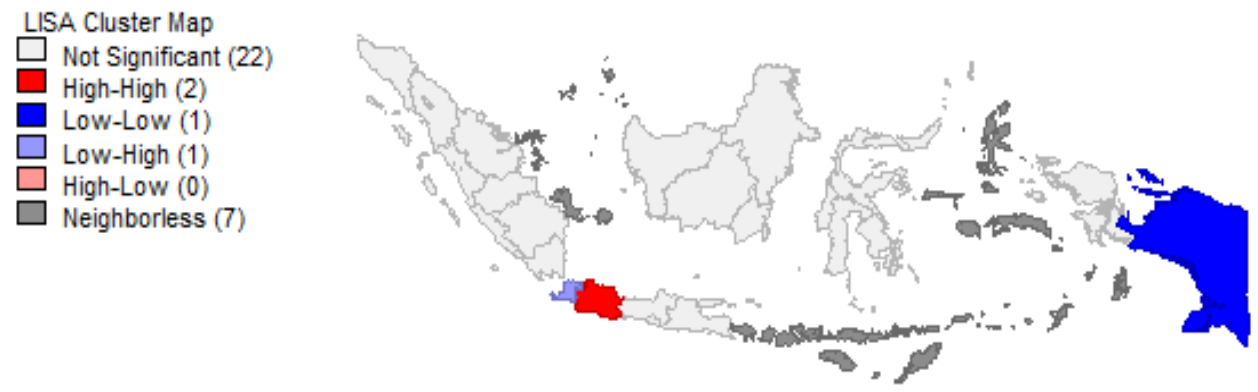

Source: GeoDa software processed data.

Figure 7 LISA significant map (see online version for colours)
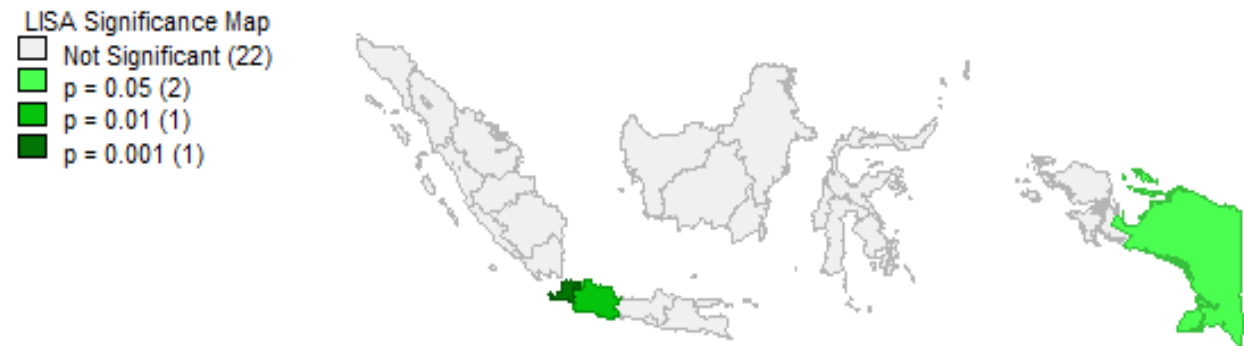

Source: GeoDa software processed data.

Indonesia is an island nation (archipelagic), spatial role in a province cannot be avoided along with the spill-over effect. Therefore, there is a need for special attention for Bank Indonesia on spatial aspects in their way to increasing role of Islamic bank financing all over Indonesia. Such phenomenon shows government policies that stimulate Islamic bank capital are very important, such as the placement of regional budget and expenditure funds, hajj funds, and other Islamic philanthropic funds which might be a source of cheap funds for Islamic banking. At the same time, Islamic banking seeks to improve the performance and financing alignments of developing local businesses. The government needs to support the initiation of more varied sharia bank products, so that the sharia banking involved in financing infrastructure projects carried out by the local government.

Central and regional governments need to enact policies that encourage local economic growth, especially provinces that are indicated to have low financing activities surrounded by provinces with low financing (Papua), by providing incentives for Islamic bank access, electricity, tax, fuel and even streamlining regulations for business actors, and controlling inflation that encourages investment, thus the opportunity for Islamic banking to channel financing distribution.

\subsection{Lagrange multiplier}

This stage aims to make the process of selecting the best model in the spatial regression equation, with a significance level of $\mathrm{p}<0.05$ (LeSage and Pace, 2009). However, before testing the Lagrange multiplier, it is necessary to test the quality of the data through the test of normality, multicollinearity, heteroscedasticity, and spatial autocorrelation. 
Jarque-Bera test aims to test the normality of data used in a model. In this study, the Jarquen-Bera test obtained a significance value of 0.93670 or equal to $p>0.05$, so it can be concluded that the data are normally distributed (Stehlík et al., 2014). Furthermore, the multicollinearity test results obtained a variance inflation factor (VIF) value of 7.679750 or VIF $<10$, thus there is no multicollinearity among variables (Alauddin and Nghiemb, 2010). Then based on the Breusch-Pegan test results obtained a significance value of 0.55938 or equal to $\mathrm{p}>0.05$, it can be concluded that there are no symptoms of heteroscedasticity in the equation (Humaira and Nugraha, 2018). Furthermore, in the spatial dependency testing, the Moran's I value of -0.5794 was obtained, this points to the existence of negative spatial autocorrelation in the research model (Tsai, 2012).

At the stage of spatial model selection, it is done with the Lagrange multiplier, this aims to carry out the process of identifying specific spatial dependencies by using lag, error and lag dependencies and errors simultaneously through Queen Contiguity weighting. Spatial dependency diagnostic results in Table 1 shows that the probability value on the Lagrange multiplier (SAR) test is 0.04344 , then the Lagrange multiplier (SEM) test is obtained a value of 0.41848, and Lagrange multiplier (SARMA) testing of 0.10348 , therefore to consider a significant tolerance limit of 0.05 (LeSage and Pace, 2009), the best model that can be used in a spatial regression equation is to use a Lagrange multiplier (SAR). Following are the results of spatial dependency testing:

Table 1 Diagnostic spatial dependencies

\begin{tabular}{lcc}
\hline Test & Value & Prob \\
\hline Lagrange multiplier (SAR) & 4.0782 & $0.04344^{*}$ \\
Lagrange multiplier (SEM) & 0.6546 & 0.41848 \\
Lagrange multiplier (SARMA) & 4.5368 & 0.10348 \\
\hline
\end{tabular}

Note: *Significant at 0.05 .

Source: GeoDa processed data.

In the next stage is to identify the factors that influence Islamic banking financing in Indonesia by using estimates in the SAR regression model. Based on the SAR estimation results in Table 2, the following equation is obtained:

$$
\begin{aligned}
\widehat{y_{1}} & =113916-0.0238734 \sum_{j=1, i \neq j}^{n} W_{i j} y_{j}+0.00242027(R G D P) \\
& +5245.05(\text { Office })+0.748103(\text { Deposit })+\varepsilon_{i} .
\end{aligned}
$$

Table 2 Estimating spatial autoregressive model (SAR)

\begin{tabular}{lcccc}
\hline \multirow{2}{*}{ Variable } & \multicolumn{4}{c}{ SAR } \\
\cline { 2 - 5 } & Coefficient & Std. error & $z$-value & Probability \\
\hline$\rho$ & -0.0238734 & 0.0112145 & -2.1288 & 0.03327 \\
Constant & 113916 & 202066 & 0.563756 & 0.57292 \\
GDP & 0.00242027 & 0.000686951 & 3.52321 & $0.00043^{*}$ \\
Office & 5245.05 & 4343.17 & 1.20766 & 0.22718 \\
Deposit & 0.748103 & 0.00846116 & 88.4161 & $0.00000^{*}$ \\
$\mathrm{R}^{2}$ & \multicolumn{4}{c}{0.998632} \\
\hline
\end{tabular}

Note: *Significant at 0.01 .

Source: GeoDa processed data. 
Through the SAR estimation test results in Table 2, there are variables that have a significance level of probability $<0.05$, namely the GDP and deposit variables. These variables included in the prediction process in the SAR equation. Based on the SAR prediction results in Table 3 , the following equation can be formed:

$$
\begin{aligned}
y_{1}= & 169205-0.0184175 \sum_{j=1, i \neq j}^{n} W_{i j} y_{j}+0.00305805(R G D P) \\
& +0.747039 \text { (Deposit })+\varepsilon_{i} .
\end{aligned}
$$

Table 3 Predictor spatial autoregressive model (SAR)

\begin{tabular}{lcccc}
\hline Variable & \multicolumn{4}{c}{ SAR } \\
\cline { 2 - 5 } & Coefficient & Std. error & z-value & Probability \\
\hline$\rho$ & -0.0184175 & 0.0104545 & -1.76168 & 0.07812 \\
CONSTANT & 169205 & 201319 & 0.840485 & 0.40064 \\
GDP & 0.00305805 & 0.000448042 & 6.82538 & $0.00000^{*}$ \\
Deposit & 0.747039 & 0.00859808 & 86.8844 & $0.00000^{*}$ \\
$\mathrm{R}^{2}$ & \multicolumn{5}{c}{0.998571} \\
\hline
\end{tabular}

Note: *Significant at 0.01 .

Source: GeoDa processed data.

Table 3 shows that the coefficient value of the predictor variable is GDP of 0.00305805 . The equation also refers to the coefficient value on the deposit variable that is equal to 0.747039. Model shows that there is a significant influence between the predictor variable and the dependent variable with a probability value $<0.005$. The value of $\mathrm{R}^{2}$ for the equation is 0.998632, meaning that all independent variables used in the SAR equation have an influence of $99.8 \%$ on the dependent variable.

Spatial regression analysis focuses on three important factors, external factors are represented by GDP variables, internal factors are represented by deposit variables and territorial factors are represented by branch distribution variables. Based on the results of the level of spatial significance, it is pointed out that the GDP and deposit variables over the province are the main factors that increase Islamic banking financing. The increased economic growth and deposit rates in an area directly, increasing the distribution of funding. The more the economy grows in an area, the more funding is needed to grow up business sector in the area. When the deposit amount increases, the banking system will indirectly have a better ability to finance the business sector.

\section{Conclusions}

Based on the findings of this study, Indonesia is absolutely an archipelago, agglomeration in nature, either gives positive or negative influence to the economic growth. It is not the growth of financial industry that matters, but GDP that mater to influence financial industry. As it shown that Global Moran's I value of the model incurs a positive spatial autocorrelation relationship among provinces of Indonesia. The spatial influence in this research model is very strong. This study also reveals that there are similarities in values 
obtained from neighbouring provinces that tend to cluster in dealing with Islamic bank financing.

The analysis concludes that only two provinces are included in the high-high category, namely Jakarta and West Java. One province included in the category of low-low namely Papua province. One province in the category of low-high, namely the Province of Banten. Islamic bank financing on Papua is actually badly lagging, and Banten Province is also special case and need even more attention, it has low value even though its neighbours perform well. Papua is less Muslim in population and Banten is more Muslim in population, for both are less developed than other provinces. Religiosity might be a factor but development is actual one.

For all archipelagic provinces that carry out operational activities of Islamic banking there are only four provinces that meet the tolerance level of significance, these four obviously have spatial relation aspect with the neighbouring provinces, namely Jakarta, West Java, Banten Province and Papua. Indonesia still has many provinces (22), as a majority, that fall into spatially insignificant category namely Gorontalo, Southeast Sulawesi, DI Yogyakarta, Central Java, East Java, South Kalimantan, West Kalimantan, South Sulawesi, Riau, Central Sulawesi, East Kalimantan, North Sulawesi, West Papua, North Sumatra, West Sumatra, Central Kalimantan, South Sumatra, Jambi, Lampung, Bengkulu, Aceh and West Sulawesi. Then it is found that seven provinces included in the category of neighbour less, as a result of missing values or isolation namely the provinces of West Nusa Tenggara, North Maluku, Maluku, East Nusa Tenggara, Bali, Bangka Belitung, and Riau Islands.

At the identification stage of Islamic banking financing factors, it can be seen that the spatial GDP and deposit have a significant influence toward financing. Islamic bank is actually still underperformed in dealing with financial inclusion in Indonesia, it is all entirely not because of voluntary reason of religiosity only, it is all about Islamic bank being 'a bank' that always consider economic growth to channel financing. Geographical spatially insignificant or economic aggregation that not evenly distributed in Indonesia is strong enough to make Islamic bank surrender. Islamic bank still has no enough ammunition to combat financial exclusion for most of the provinces, even though they have reasonable counter mechanism to face the challenges but certainly Islamic banks still need more 'bank time' to grow.

The government through BI and OJK needs to improve the human resources sector. Providing understanding and awareness of literacy of Islamic banking to the public. In addition, further research is needed in each province, related to the extent of sharia financial literacy in each region in Indonesia. Thus, the role of BI as the regulator and OJK as the supervisor might run optimally, especially in regions that are indicated to have no significance on inter-regional influence.

\section{References}

Abduh, M. and Chowdhury, N.T. (2012) 'Does Islamic banking matter for economic growth in Bangladesh ?', Journal of Islamic Economics, Banking and Finance, Vol. 8, No. 3, pp.105-113.

Abedifar, P., Molyneux, P. and Tarazi, A. (2013) 'Risk in Islamic banking', Review of Finance, Vol. 17, No. 6, pp.2035-2096, https://doi.org/10.1093/rof/rfs041. 
Alauddin, M. and Nghiemb, H.S. (2010) 'Do instructional attributes pose multicollinearity problems? An empirical exploration', Economic Analysis and Policy, Vol. 40, No. 3, pp.351-361, https://doi.org/10.1016/S0313-5926(10)50034-1.

Anselin, L. (2005) Exploring Spatial Data with GeoDa : A Workbook, Center for Spatially Integrated Social Science, Santa Barbara.

Ansong, D., Chowa, G. and Adjabeng, B.K. (2015) 'Spatial analysis of the distribution and determinants of bank branch presence in Ghana', International Journal of Bank Marketing, Vol. 33, No. 3, pp.201-222, https://doi.org/10.1108/IJBM-09-2013-0103.

Bangake, C. and Eggoh, J.C. (2011) 'Further evidence on finance-growth causality: a panel data analysis', Economic Systems, Vol. 35, No. 2, pp.176-188, https://doi.org/10.1016/j.ecosys.2010.07.001.

Basar, O.D. and Genc, E.G. (2015) 'The analysis of bank deposits through spatial modelling by provinces', International Journal of Financial Research, Vol. 7, No. 1, pp.91-100, https://doi.org/10.5430/ijfr.v7n1p91.

Beck, T., Ongena, S. and Şendeniz-Yüncü, İ. (2019) 'Keep walking? Geographical proximity, religion, and relationship banking', Journal of Corporate Finance, Vol. 55, pp.49-68, https://doi.org/10.1016/j.jcorpfin.2018.07.005.

Bellucci, A., Borisov, A. and Zazzaro, A. (2013) 'Do banks price discriminate spatially? Evidence from small business lending in local credit markets', Journal of Banking \& Finance, Vol. 37, No. 11, pp.4183-4197, https://doi.org/10.1016/j.jbankfin.2013.06.009.

Ben Naceur, S., Barajas, A. and Massara, A. (2015) Can Islamic Banking Increase Financial Inclusion?, IMF Working Papers, Vol. 15, https://doi.org/10.5089/9781498370813.001.

Cai, W., Xu, F. and Zeng, C. (2016) 'Geographical diversification and bank performance: evidence from China', Economics Letters, Vol. 147, No. 71402005, pp.96-98, https://doi.org/10.1016/j.econlet.2016.08.022.

Combey, A. and Togbenou, A. (2017) 'The bank sector performance and macroeconomics environment: empirical evidence in Togo', International Journal of Economics and Finance, Vol. 9, No. 2, p.180, https://doi.org/10.5539/ijef.v9n2p180.

Crocco, M., Faria-Silva, F., Paulo-Rezende, L. and Rodríguez-Fuentes, C.J. (2014) 'Banks and regional development: an empirical analysis on the determinants of credit availability in Brazilian Regions', Regional Studies, Vol. 48, No. 5, pp.883-895, https://doi.org/10.1080/00343404.2012.697141.

Davidson, N. and Mariev, O. (2018) 'The impact of spatial concentration on enterprise performance: is localisation level optimal in Russia?', International Journal of Economic Policy in Emerging Economies, Vol. 11, No. 6, pp.522-540, https://doi.org/10.1504/IJEPEE.2018.095933

Degl'Innocenti, M., Matousek, R., Sevic, Z. and Tzeremes, N.G. (2017) 'Bank efficiency and financial centres: does geographical location matter?', Journal of International Financial Markets, Institutions and Money, Vol. 46, pp.188-198, https://doi.org/10.1016/j.intfin.2016.10.002.

Degryse, H. and Ongena, S. (2005) 'Distance, lending relationships, and competition', The Journal of Finance, Vol. 60, No. 1, pp.231-266, https://doi.org/10.1111/j.1540-6261.2005.00729.x.

Dimitrios, A., Helen, L. and Mike, T. (2016) 'Determinants of non-performing loans: evidence from Euro-area countries', Finance Research Letters, Vol. 18, October 2017, pp.116-119, https://doi.org/10.1016/j.frl.2016.04.008.

Fernandez, V. (2011) 'Spatial linkages in international financial markets', Quantitative Finance, Vol. 11, No. 2, pp.237-245, https://doi.org/10.1080/14697680903127403.

Gheeraert, L. and Weill, L. (2015) 'Does Islamic banking development favor macroeconomic efficiency? Evidence on the Islamic finance-growth nexus', Economic Modelling, Vol. 47, October 2011, pp.32-39, https://doi.org/10.1016/j.econmod.2015.02.012. 
Hachicha, N. and Ben Amar, A. (2015) 'Does Islamic bank financing contribute to economic growth? The Malaysian case', International Journal of Islamic and Middle Eastern Finance and Management, Vol. 8, No. 3, pp.349-368, https://doi.org/10.1108/IMEFM-07-2014-0063.

Hakam, A., Fatine, F.A. and Zakaria, F. (2013) 'Determinants of banking competition in Morocco and evaluation of the structural reforms', International Journal of Economics and Financial Issues, Vol. 3, No. 2, pp.447-465.

Hamza, H. and Saadaoui, Z. (2013) 'Investment deposits, risk-taking and capital decisions in Islamic banks', Studies in Economics and Finance, https://doi.org/10.1108/SEF-Feb-20120016.

Harmes, H., Juanda, B., Rustiadi, E. and Barus, B. (2017) 'Pemetaan efek spasial pada data kemiskinan Kota Bengkulu', Journal of Regional and Rural Development Planning, Vol. 1, No. 2, p.192, https://doi.org/10.29244/jp2wd.2017.1.2.192-201.

Hazar, A. and Babuscu, S. (2013) 'Turkish banking sector credit-deposit developments regionally analysis (2005-2011)', Journal of Cankurl Karatekin University Economics and Administrative Sciences, Vol. 3, No. 1, pp.93-119.

Humaira, U.H. and Nugraha, J. (2018) 'Analysis of factors affecting the human development Index in West Kalimantan Province using data panel data regression', Jurnal Eksakta, Vol. 18, No. 2, pp.97-105, https://doi.org/10.20885/eksakta.vol18.iss2.art2.

Ismal, R. (2010) Volatility of the Returns and Expected Losses of Islamic Bank Financing, https://doi.org/10.1108/17538391011072453.

Jiménez, G., Salas, V. and Saurina, J. (2009) 'Organizational distance and use of collateral for business loans', Journal of Banking \& Finance, Vol. 33, No. 2, pp.234-243, https://doi.org/10.1016/j.jbankfin.2008.07.015.

Kakilli Acaravci, S. and Çalim, A.E. (2013) 'Turkish banking sector's profitability factors', International Journal of Economics and Financial Issues, Vol. 3, No. 1, pp.27-41.

Kayed, R.N. (2012) 'The entrepreneurial role of profit-and-loss sharing modes of finance: theory and practice', International Journal of Islamic and Middle Eastern Finance and Management, https://doi.org/10.1108/17538391211255205.

Kolomak, E. (2013) 'Spatial inequalities in Russia: dynamic and sectorial analysis', International Journal of Economic Policy in Emerging Economies, Vol. 6, No. 4, pp.375-402, https://doi.org/10.1504/IJEPEE.2013.057910.

Lee, N. and Brown, R. (2017) 'Innovation, SMEs and the liability of distance: the demand and supply of bank funding in UK peripheral regions', Journal of Economic Geography, Vol. 17, No. 1, pp.233-260, https://doi.org/10.1093/jeg/lbw011.

LeSage, J. and Pace, R.K. (2009) 'Introduction to spatial econometrics', in Balakrishnan, N. and Schucany, W.R. (Eds.): Introduction to Spatial Econometrics, pp.1-321, CRC Press, Boca Raton.

Leyshon, A., French, S. and Signoretta, P. (2008) 'Financial exclusion and the geography of bank and building society branch closure in Britain', Transactions of the Institute of British Geographers, Vol. 33, No. 4, pp.447-465, https://doi.org/10.1111/j.1475-5661.2008.00323.x.

Liberti, J.M. and Petersen, M.A. (2019) 'Information: hard and soft', The Review of Corporate Finance Studies, Vol. 8, No. 1, pp.1-41, https://doi.org/10.1093/rcfs/cfy009.

Marshall, J.N. (2013) 'A geographical political economy of banking crises: a peripheral region perspective on organisational concentration and spatial centralisation in Britain', Cambridge Journal of Regions, Economy and Society, Vol. 6, No. 3, pp.455-477, https://doi.org/10.1093/cjres/rst002.

Mirzaei, A., Moore, T. and Liu, G. (2013) 'Does market structure matter on banks' profitability and stability? Emerging vs. advanced economies', Journal of Banking and Finance, Vol. 37, No. 8, pp.2920-2937, https://doi.org/10.1016/j.jbankfin.2013.04.031.

Mohiedlien, M., Rostom, A. and Iqbal, Z. (2012) 'The role of islamic finance in enhancing financial inclusion in organization of Islamic cooperation (OIC) countries', The World Bank Islamic Economics and Finance Working group, Vol. 2, No. 20, pp.2-55.

Obaidullah, M. (2005) Islamic Financial Services, Scientific Publishing Center, Jeddah. 
Rati, M., Nababan, E. and Sutarman. (2013) 'Model regresi spasial untuk anak tidak bersekolah usia kurang 15 tahun di kota medan', Saintia Matematika, Vol. 1, No. 1, pp.87-99.

Richards, T.J., Acharya, R.N. and Kagan, A. (2008) 'Spatial competition and market power in banking', Journal of Economics and Business, Vol. 60, No. 5, pp.436-454, https://doi.org/10.1016/j.jeconbus.2007.06.002.

Sahara, A.Y. (2013) Analisis Pengaruh Inflasi, Suku Bunga BI, dan Produk Domestik Bruto, Terhadap ROA Bank Syariah, Vol. 1.

Samad, A., Ashraful, M. and Chowdhury, F. (2017) 'Islamic banks' return on depositors and conventional banks' deposit interest: is there causality?, Evidence of causality from Bangladesh', International Journal of Economics and Financial Issues, Vol. 7, No. 5, pp.432-439.

Soedarmono, W., Trinugroho, I. and Sergi, B.S. (2019) 'Thresholds in the nexus between financial deepening and firm performance: evidence from Indonesia', Global Finance Journal, Vol. 40, No. 623, pp.1-12, https://doi.org/10.1016/j.gfj.2018.08.001.

Soewarno, N. and Ali, H. (2016) 'Impact of regulation and supervision on Indonesian banks' scale efficiency, 2002-2011', International Journal of Economic Policy in Emerging Economies, Vol. 9, No. 4, pp.404-424, https://doi.org/10.1504/IJEPEE.2016.081410.

Sohag, K., Nabilah, A.B. and Begum, R.A. (2015) 'Dynamic impact of financial development on economic growth: heterogeneous panel data analysis of island economies', International Journal of Economic Policy in Emerging Economies, Vol. 8, No. 1, pp.77-95, https://doi.org/10.1504/IJEPEE.2015.068249.

Stehlík, M., Střelec, L. and Thulin, M. (2014) 'On robust testing for normality in chemometrics', Chemometrics and Intelligent Laboratory Systems, Vol. 130, pp.98-108, https://doi.org/10.1016/j.chemolab.2013.10.010,

Sufian, F. and Habibullah, M.S. (2010) 'Does economic freedom fosters banks' performance? Panel evidence from Malaysia', Journal of Contemporary Accounting \& Economics, Vol. 6, No. 2, pp.77-91, https://doi.org/10.1016/j.jcae.2010.09.003.

Tabash, M.I. and Dhankar, R.S. (2014) 'Islamic finance and economic growth: an empirical evidence from United Arab Emirates (UAE)', Journal of Emerging Issues in Economics, Finance and Banking (JEIEFB), Vol. 3, No. 2, pp.1069-1085.

Trinugroho, I., Ariefianto, M.D., Nugroho, L.I., Sawitri, H.S.R., Prabowo, M.A., Harmadi and Hakim, L. (2018) 'What determine the viability of rural banks? Evidence from Indonesia', International Journal of Economics and Management, Vol. 12, No. 2, pp.369-378.

Tsai, P-J. (2012) 'Application of Moran's test with an empirical Bayesian rate to leading health care problems in Taiwan in a 7-year period (2002-2008)', Global Journal of Health Science, Vol. 4, No. 5, pp.63-77, https://doi.org/10.5539/gjhs.v4n5p63.

Wang, X. and Guan, J. (2017) 'Financial inclusion: measurement, spatial effects and influencing factors', Applied Economics, Vol. 49, No. 18, pp.1751-1762, https://doi.org/10.1080/00036846.2016.1226488.

Zamer, K.Z. (2018) 'Islamic banking: a new approach for financial inclusion', International Journal of Economics and Finance, Vol. 10, No. 7, p.118, https://doi.org/10.5539/ijef.v10n7p118

Zhukov, Y M. (2010) Spatial Autocorrelation, Harvard University, USA.

\section{Notes}

1 The Financial Services Authority or Otoritas Jasa Keuangan (OJK) is an Indonesian government agency which regulates and supervises the financial services sector.

2 Bank Indonesia (BI) is the central bank of the Republic of Indonesia. 